\title{
Improving Capacity For Phytoremediation Of Vetiver Grass And Indian Mustard In Heavy Metal (Al And Mn) Contaminated Water Through The Application Of Clay Minerals
}

\author{
Beatrice Omonike Otunola ( $\nabla$ omobeat15@gmail.com ) \\ University of the Free State https://orcid.org/0000-0003-4144-4794 \\ Makhosazana P. Aghoghovwia \\ University of the Free State \\ Melusi Thwala \\ University of the Free State \\ Alba Gómez-Arias \\ University of the Free State \\ Rian Jordaan \\ University of the Free State \\ Julio Castillo Hernandez \\ University of the Free State \\ Olusola Oluwayemisi Ololade \\ University of the Free State
}

\section{Research Article}

Keywords: Heavy metals, Indian mustard, phytoremediation, contaminated water, Vetiver grass.

Posted Date: February 15th, 2022

DOI: https://doi.org/10.21203/rs.3.rs-1178166/v1

License: (c) (7) This work is licensed under a Creative Commons Attribution 4.0 International License. Read Full License 


\section{Abstract}

Phytoremediation of areas contaminated by heavy metals using Vetiver grass and Indian mustard is cost-effective and environmentally friendly. However, strategies to optimize the remediation capacity of these plants to be more sustainable in combatting environmental pollution is lacking. This study aimed at enhancing remediation of heavy metal contaminated water through the simultaneous hybrid application of clay minerals (attapulgite and bentonite) and Vetiver grass or Indian mustard. A 21-day greenhouse experiment was carried out to investigate the effectiveness of the clay minerals to improve heavy metal phytoremediation. Attapulgite successfully improved the growth and tolerance index of Vetiver grass in heavy metal contaminated water. The addition of clay minerals did not, however, increase the tolerance of Indian mustard for Al and $\mathrm{Mn}$. The best efficiency was from a hybrid system of $2.5 \%(\mathrm{w} / \mathrm{v})$ bentonite treatment with Vetiver grass. However, Indian mustard showed no significant uptake of heavy metals, but suffered heavy metal toxicity despite the addition of clay minerals. The current laboratory-scale findings provided a basis for field trials earmarked for remediation in a post-mining coal environment in South Africa.

\section{Highlights}

- Attapulgite and bentonite assisted phytoremediation of Vetiver grass for $\mathrm{Al}$ and $\mathrm{Mn}$.

- Bentonite $(2.5 \% \mathrm{w} / \mathrm{v})$ improved phytoremediation capacity of Vetiver grass for Al.

- Attapulgite $(2.5 \% \mathrm{w} / \mathrm{v})$ improved Vetiver grass tolerance index for Al and $\mathrm{Mn}$.

- Clay minerals did not increase Indian mustard's tolerance for Al and Mn.

\section{Introduction}

Water is a scarce resource in most parts of the world and when affected by pollution, the proper ecosystem functioning and suitability for use diminishes. The rising human population drives industrialization, mining, agriculture, and poor sewage management, which then become major water resource pollutants (Danh et al., 2009). Of the various contaminants, heavy metals are constantly released into the environment from a multitude of anthropogenic sources, posing a risk to human and environmental health (Danh et al., 2009; Beniah Obinna and Ebere, 2019). The main sources of heavy metals pollutants are mining, manufacturing and processing industries, sewage, solid wastes, urban runoff, fuel leakages (WHO, 2017). Humans can readily ingest heavy metals by consuming contaminated water and aquatic biota (Beniah Obinna and Ebere, 2019).

Increased levels of trace metals in rivers are associated with mining and other industrial activities (Ali et al., 2018). For example, in South Africa, industrial effluents that end up in the Vaal River contained $14 \mathrm{mg} / \mathrm{l} \mathrm{Al}, 56.7 \mathrm{mg} / \mathrm{l} \mathrm{Zn}$ and $4.6 \mathrm{mg} / \mathrm{l} \mathrm{Pb}$, which are toxic at concentrations above $0.01 \mathrm{mg} / \mathrm{l}$ for $\mathrm{Pb}$ and $0.1 \mathrm{mg} / \mathrm{l}$ for $\mathrm{Zn}$ and Al (lloms et al., 2020). Another example is the Leeuspruit River in proximity to a former coal mine which records concentrations of $2.72 \mathrm{mg} / \mathrm{L}$ and $5.4 \mathrm{mg} / \mathrm{L}$ for $\mathrm{Mn}$ and Al respectively (Wessels, 2013). Al and Mn are among the most abundant elements in the earth's crust. Al in nature is from weathered aluminosilicate rocks and minerals (Wang et at., 2013). It is useful in various sectors and essential in production of many domestic products. There is evidence that solubilized Al in toxic amounts negatively affects plants, animals and human beings. E.g., root growth inhibition in plants, nervous disorders and Alzheimer's disease in humans (Wang et al., 2013). Likewise, Mn is applied in production of various materials such batteries, glass, fireworks, fertilisers, cleaning products and cosmetics (WQA, 2021). Excess Mn levels in human beings can result to several health issues such as neurological disorders, low IQ in children and low coordination and movement control (Wang et al., 2013). In Ecuador, elevated levels of Mn (970 $\mu \mathrm{g} / \mathrm{L}$ ) was detected in the Puyango River and children in proximity to this river had over $2 \mu \mathrm{g} / \mathrm{g}$ in their hair. This was found to be responsible for neurobehavioral disorders and low IQ among these children (Betancourt et al., 2015).

Over the years, the ecological and human health concerns of heavy metals have given rise to innovative solutions to rid them from contaminated sites and water bodies. One of the most accepted methods is phytoremediation, because it is affordable, and easily applied green technology whose by products can be used for other purposes such as bioenergy, essential oils and animal feed (Sricoth et al., 2018; Yang et al., 2019; Edgar et al., 2021). However, wider application of phytoremediation is inhibited by various challenges, including low biomass yield, extreme climatic influence, slow plant growth, long time required for remediation, pollutant-specific requirements, and adverse effects of contaminants on plant functions (Danh et al., 2009; Mioska, 2012; Shahid et al., 2020; Leng et al., 2021; Sharma, 2021).

Vetiver grass (Chrysopogon zizanioides) is notable in water remediation, because of its excellent physiological and morphological properties, which enable growth in contaminated substrates and under harsh climatic conditions (Truong and Hartm, 2001; Danh et al., 2009; Koupai et al., 2020). Kiiskila et al. (2019) observed that Vetiver removed $\mathrm{Ni}, \mathrm{Zn}$, sulphate, $\mathrm{Mn}$, $\mathrm{Cr}$, Al and Cu by 38\%, 35\%, 28\%, 27\%, 21\%, 11 and $8 \%$ respectively from acid mine drainage. The authors noted up to $81 \%$ removal of $\mathrm{Fe}$ and $\mathrm{Pb}$ within a year. Indian mustard (Brassica juncea) is also recognized as a good plant for phytoremediation (Qadir et al., 2004; Rehana et al., 2012; Raj et al., 2020), although studies on 
water remediation in the field are limited. Some studies on the phytoremediation capacity of Indian mustard have confirmed its ability to survive and absorb heavy metals with concentrations as high as 50 ppm in substrates (Meyers et al., 2008; Singh and Fulekar, 2012; Napoli et al., 2019). Singh and Fulekar (2012) observed that Indian mustard absorbed 25,000 ppm, 32,750 ppm and 30,550 ppm of $\mathrm{Cd}$, Pb and Zn from water and soil, respectively, after 21 days of exposure. Raj et al. (2020), remediated $\mathrm{Hg}$ contaminated fly ash in pot experiments using Indian mustard for up to 90 days with a heavy metal accumulation of up to $2.62 \mathrm{mg} / \mathrm{kg}$, mostly in the roots followed by leaves and stems. Based on the bioconcentration factor (range 0.1-1), Indian mustard is classified as a moderate $\mathrm{Hg}$ accumulator (Raj et al., 2020).

Recently, clay minerals and nanoparticles have received attention for application in the remediation of contaminated soil and water (Otunola and Ololade, 2020; Hussain et al., 2021). A review by Paz-Ferreiro et al. (2014) confirmed the use of several soil amendments such as biochar and compost in combination with hyperaccumulators for better remediation results. The approach of using immobilisers to improve phytoremediation has been tested in the laboratory showing increased phytoextraction of $\mathrm{Pb}$ and $\mathrm{Sb}$, up to 533 times higher than phytoextraction alone without amendments (Katoh et al., 2016). Clay minerals play an important role is soil fertility because the soil structures depend on the proportion and types of clays present. These affect organic matter, nutrient and water retention capability of soil. Clays also buffer pH changes, and control soil microbial activities (Kome et al., 2019). In water, clays can control pH and provide adsorptive properties for heavy metals and other nutrients (Otunola and Ololade, 2020). These properties of clay minerals can improve phytoremediation (Salimizadeh et al., 2020).

In pursuit of sustainable solutions to environmental pollution and the associated challenges of phytoremediation, the present study's aim was to optimize the remediation of heavy metal contaminated water through a hybrid application of phytoremediation (using Vetiver grass and Indian mustard) and clay minerals (attapulgite and bentonite). In particular, the study investigated the impact of attapulgite and bentonite at two dosage levels ( $1 \%$ and $2.5 \%$ ) on the growth and phytoremediation potential of Vetiver grass and Indian mustard in water. These dosage levels were chosen, because low clay dosages (between 0.5 and $8 \mathrm{~g} / \mathrm{kg}$ ) were effective in previous research (Zotiadis and Argyraki, 2013; Otunola and Ololade, 2020). Attapulgite and bentonite were selected for this study, because of their potential to adsorb and eliminate heavy metals from polluted water (Otunola and Ololade, 2020) and their capacity to serve as amendments that could improve soil properties and alleviate heavy metal toxicity in plants heavy metals (Salimizadeh et al., 2020; Otunola and Ololade, 2020). This experiment was carried out to evaluate the heavy metal uptake by Vetiver grass and Indian mustard under the influence of bentonite and attapulgite to decide the best treatment for small-scale field experiments. This application will be undertaken to develop a suitable solution for the remediation of heavy metals in a post-mining environment in Sasolburg, South Africa.

\section{Materials And Methods}

i. Water sampling

The study area is around a former coal mining area located in Sasolburg, Free State Province, South Africa. Mining operations were stopped in 2006 and the area is now at the rehabilitation and reclamation stage. Previous monitoring of this area established that the Leeuspruit River ( $\left.26^{\circ} 50^{\prime} 16.1^{\prime \prime S} 27^{\circ} 48^{\prime} 42.3^{\prime \prime} \mathrm{E}\right)$, one of the major water bodies in the area is polluted by nutrients and heavy metals including $\mathrm{Al}$ and $\mathrm{Mn}$, emanating from mining as well as post-mining land-use activities (Wessels, 2013).

Physicochemical water parameters, including $\mathrm{pH}$, temperature, electrical conductivity (EC), and total dissolved solids (TDS) were measured on-site using a calibrated standard multi-parameter probe (YSI Incorporated, Model 85D, I.N058500, SN 09K 100684, Yellow Springs, Ohio, USA). To determine the heavy metal concentrations, water samples were collected in triplicate from four sites along the course of the river, based on land use patterns and suspected pollution sources. Clean $500 \mathrm{~mL}$ polyethylene bottles were rinsed three times with the river water before samples were collected and stored in cooler boxes with ice. The samples were transported to the Institute for Groundwater Studies at the University of the Free State for heavy metal and nutrient analyses.

ii. Plant preparation

Vetiver grass (C. zizanioides) was supplied by Hydromulch (Pty) Ltd. Johannesburg, South Africa. The plants were thoroughly rinsed to remove soil particles and other possible contaminants and then trimmed to similar shoot and root lengths of 30 and $15 \mathrm{~cm}$, respectively. Indian mustard ( $B$. juncea) seeds were supplied by Seeds for Africa, South Africa. These were propagated in seedling trays using Hygrotech seedling starter composed of $\mathrm{N}(17.2 \%), \mathrm{P}(7.1 \%), \mathrm{K}(2.3 \%), \mathrm{Ca}(0.8 \%), \mathrm{Mg}(0.2 \%), \mathrm{Fe}(785 \mathrm{mg} / \mathrm{kg}), \mathrm{Mn}, \mathrm{Zn}$ and Cu $(398 \mathrm{mg} / \mathrm{kg}), \mathrm{B}(204$ $\mathrm{mg} / \mathrm{kg})$, and Mo $(6.6 \mathrm{mg} / \mathrm{kg})$. The seedlings were kept moist in a greenhouse at the Department of Soil, Crop and Climate Sciences, University of the Free State. Thirty-day-old seedlings of similar sizes were thoroughly rinsed and used for the experiment.

iii. Experiment set up 
A 21-day randomized complete block design hydroponic experiment was set up in a greenhouse facility at the University of the Free State, South Africa. Pots were maintained under temperatures of $28^{\circ} \mathrm{C}$ (day) and $20^{\circ} \mathrm{C}$ (night) and exposed to natural light. The treatment codes and descriptions are presented in Table 1. This study seeks to determine the best treatment using a hybrid of clay minerals and plants, nutrient water was spiked with $\mathrm{Al}(5 \mathrm{mg} / \mathrm{l})$ and $\mathrm{Mn}(1 \mathrm{mg} / \mathrm{l})$, based on the concentrations found in the Leeuspruit River (Table 2). Plastic pots of $1 \mathrm{~L}$ were used to hold $800 \mathrm{~mL}$ contaminated water. These were covered with lids that had holes and wrapped with aluminium foil to minimize the effects of sunlight. The plants were placed over the water (Figure 1). The pots were refilled to the initial volume (800 mL) with prepared water each time the water levels were reduced through evaporation, transpiration and consumption by the plants.

Table 1

Water treatment codes and conditions

\begin{tabular}{|c|c|}
\hline Treatment Code & Conditions \\
\hline Control (Zero treatment) & Prepared water \\
\hline AT1 & Attapulgite Applied at 1\% (w/v) \\
\hline AT2.5 & Attapulgite Applied at 2.5\% (w/v) \\
\hline BT1 & Bentonite applied at 1\% (w/v) \\
\hline BT2.5 & Bentonite Applied at 2.5\% (w/v) \\
\hline VT & Vetiver only (one plant per pot) \\
\hline BJ & Indian mustard only (one plant per pot) \\
\hline AT1VT & Attapulgite + Vetiver applied at 1\% (w/v) \\
\hline AT2.5VT & Attapulgite + Vetiver applied at 2.5\% (w/v) \\
\hline BT1VT & Bentonite + Vetiver applied at 1\% (w/v) \\
\hline BT2.5VT & Bentonite + Vetiver applied at 1\% (w/v) \\
\hline AT1BJ & Attapulgite + Vetiver applied at 1\% (w/v) \\
\hline AT2.5BJ & Attapulgite + Vetiver applied at 2.5\% (w/v) \\
\hline BT1BJ & Bentonite + Vetiver applied at 1\% (w/v) \\
\hline BT2.5BJ & Bentonite + Vetiver applied at 2.5\% (w/v) \\
\hline VTC & Vetiver only in nutrient water \\
\hline BJC & Indian mustard only in nutrient water \\
\hline
\end{tabular}

Figure 1: Experimental setup of the various treatments at a greenhouse facility, University of the Free State, South Africa.

i. Plant harvesting and processing

At the end of 21 days, the plants were harvested and carefully rinsed with water. The length and weight of the roots and shoots of the plants' fresh biomass were recorded. The plant sections were then separately oven-dried at $75^{\circ} \mathrm{C}$ for 72 hours. The dry biomass of each plant was weighed, recorded and the tolerance index (TI) was calculated as follows (Equation 1):

\section{$T I=D B c o n t / D B u c o n t(1)$}

Where DBcont is the total dry biomass in the contaminated medium and DBucont is the total dry biomass in the uncontaminated medium (Beniah Obinna and Ebere, 2019).

The translocation factor (TF), which is the ability of a plant to translocate metals from its roots to shoot was calculated as (Equation 2):

$T F=H m$ conc in shoot $/ \mathrm{Hm}$ conc in root (2)

Where $\mathrm{Hm}$ are the heavy metals (Beniah Obinna and Ebere, 2019).

ii. Plant sample digestion and analysis 
The dried root and shoot samples were milled and digested using microwave-assisted digestion by nitric acid. Briefly, $0.5 \mathrm{~g}$ of homogenized powdered plant sample was weighed and transferred into a microwave vessel; $15 \mathrm{~mL}$ nitric acid was added based on a modification of US EPA method 3051 (US EPA, 2007; Sastre et al., 2002). The vessel was covered, de-pressured and placed in a microwave for 25 mins (Ramp for 10 mins). After cooling, the digestate was transferred into $250 \mathrm{~mL}$ volumetric flasks, diluted, and filtered through a 0.45 syringe filter. To determine the heavy metal uptake levels in the plant roots and shoots, the digested samples were analysed using a Prodigy 7 ICP-OES Spectrometer (Teledyne Leeman Labs) at the Analytical Laboratory, Chemistry Department, University of the Free State.

iii. Statistical analysis

All data were subjected to one-way analysis of variance (ANOVA) to determine the effect of clay treatments on heavy metal adsorption. The calculations were performed using R software version 4.0.0 (R Development Core Team 2020) at a significance level of 0.05. Pearson Correlation Coefficient test was used to confirm the relationship between roots and shoots uptake.

\section{Results And Discussion}

i. Physicochemical properties and heavy metals

The physicochemical properties and heavy metal values of the water samples for each sampling site along the Leeuspruit River were compared with the In-stream Water Quality Guidelines for the Leeuspruit Catchment (In-stream WQG, 2021) (Table 2). The pH values of the water samples ranged from $6.02 \pm 0.01$ at RIV2 to $7.22 \pm 0.1$ at RIV3, indicating the pH of the Leeuspruit was close to neutral. The highest temperature was $29.8 \pm 0.1 \otimes \mathrm{C}$ at RIV3 while the average temperature of the river was $26.38 \llbracket \mathrm{C}$. All the pH and temperature values were within the Leeuspruit Catchment Water Quality Limits. The mean values of EC and $\mathrm{SO}_{4}{ }^{2-}$ were $104.18 \mathrm{mS} / \mathrm{m}$ and $91.26 \mathrm{mg} / \mathrm{L}$, respectively. There was a high variation in the TDS values among the sample points, which ranged from $240 \pm 0.70 \mathrm{mg} / \mathrm{L}$ to $965 \pm 0 \mathrm{mg} / \mathrm{L}$. The possible sources of the dissolved solids may have been from the dissolution of underlying sedimentary rocks or runoff from agricultural land (Fondriest Environmental, 2014). Based on the Leeuspruit Catchment Water Quality Guidelines, ideal EC values were exceeded in all the sites except for RIVC (Table 2). The lowest $\mathrm{PO}_{4}{ }^{3-}$ value was $0.24 \pm 0.35 \mathrm{mg} / \mathrm{L}$ from RIVC, which were within the acceptable limits of the Leeuspruit Catchment Water Quality Guidelines. The highest $\mathrm{PO}_{4}{ }^{3-}$ values of $2.06 \pm 0.61 \mathrm{mg} / \mathrm{L}$ was from RIV4, which exceeded this limit by $1.66 \mathrm{mg} / \mathrm{L}$. High phosphate levels can promote eutrophication, lowering overall water quality (Mezgebe et al., 2015). The $\mathrm{SO}_{4}{ }^{2-}$ concentrations ranged from $13.7 \pm 0.41 \mathrm{mg} / \mathrm{L}$ to $238.7 \pm 1.44 \mathrm{mg} / \mathrm{L}$ (RIV3), with a mean value of $91.26 \mathrm{mg} / \mathrm{l}$, indicating mine water pollution. The ICP-OES results revealed that $\mathrm{Mn}$ ranged from $0.14 \pm 0.003$ to $0.54 \pm 0.001 \mathrm{mg} / \mathrm{L}$ while Al ranged from $0.33 \pm 0.01$ to $4.58 \pm$ $0.002 \mathrm{mg} / \mathrm{L}$. The result for other heavy metals such as Cd, As, Co, Cr, Mo, and Cu were below detection limits. Al and Mn with concentrations of $\sim 5 \mathrm{mg} / \mathrm{L}$ and $1 \mathrm{mg} / \mathrm{L}$ respectively were of importance in this research.

ii. Tolerance index (TI) and visual symptoms

Attapulgite and bentonite were investigated for their ability to improve the growth of Vetiver grass and Indian mustard in Al and Mn contaminated water. The rate of phytoremediation is affected by plant growth rate, which is why fast-growing and high biomass crops are the most appropriate (Danh et al., 2009; Beniah Obinna and Ebere 2019; Itam et al., 2019). Although TI varied within the different treatments, both plants showed a high tolerance with $\mathrm{TI}>60$ (Figures 2 and 3). The TI of Vetiver grass was significantly higher in the treatments assisted with attapulgite and bentonite. Attapulgite gave the best growth improvement with TI of $107.7 \%$ in the AT2.5VT treatment, while the lowest $\mathrm{TI}$ of $62.9 \%$ was obtained in the Vetiver grass + control (Figure $2 \mathrm{a}$ ). This indicates that attapulgite and bentonite alleviated heavy metal stress in Vetiver grass. For the Indian mustard treatments, the highest TI was 116.8\% with the BJ treatment (Indian mustard + control), while the lowest $\mathrm{TI}$ of $76.2 \%$ was in the AT2.5 BJ treatment (Figure 3a), indicating that the clay minerals did not improve the metal tolerance of Indian mustard. Despite the addition of more contaminated water leading to increased concentrations of Al and Mn, Vetiver grass showed no physical signs of heavy metal stress. The plant remained green and luscious throughout the experiment (Figure $2 \mathrm{~b}$ ), while Indian mustard became pale and yellowish with leaves drying out due to heavy metal stress (Figure $3 \mathrm{~b}$ ). This confirms that Vetiver has the ability to survive in highly contaminated environments (Danh et al., 2009; Suelee et al., 2017). This is similar to the observation of Gravand and Rahnavard (2021), who noted that there were no physical signs of toxicity in Vetiver grass in highly contaminated media.

Table 2: Physicochemical parameters and heavy metals ( \pm standard deviation) measured in-situ and laboratory chemical analysis of water samples from the Leeuspruit Assessment against the In-stream Water Quality Guidelines (WQG) for the Leeuspruit Catchment. EC: electrical conductivity; TDS: total dissolved solids 


\begin{tabular}{|c|c|c|c|c|c|c|c|c|c|}
\hline $\begin{array}{l}\text { Sampling site } \\
\text { and WQC values }\end{array}$ & $\mathrm{pH}$ & $\begin{array}{l}\text { Temperature } \\
\left({ }^{\circ} \mathrm{C}\right)\end{array}$ & $\begin{array}{l}\mathrm{EC} \\
(\mathrm{mS} / \mathrm{m})\end{array}$ & $\begin{array}{l}\text { TDS } \\
(\mathrm{mg} / \mathrm{L})\end{array}$ & $\mathrm{NO}_{3}{ }^{-}(\mathrm{mg} / \mathrm{L})$ & $\begin{array}{l}\mathrm{PO}_{4}{ }^{3-} \\
(\mathrm{mg} / \mathrm{L})\end{array}$ & $\begin{array}{l}\mathrm{SO}_{4}{ }^{2-} \\
(\mathrm{mg} / \mathrm{L})\end{array}$ & $\begin{array}{l}\text { Al } \\
(\mathrm{mg} / \mathrm{L})\end{array}$ & $\begin{array}{l}\mathrm{Mn} \\
(\mathrm{mg} / \mathrm{L})\end{array}$ \\
\hline RIVC & $\begin{array}{l}6.02 \\
\pm \\
0.01\end{array}$ & $25.5 \pm 0.40$ & $\begin{array}{l}39.3 \pm \\
0.50\end{array}$ & $\begin{array}{l}240 \pm \\
0.70\end{array}$ & $0.06 \pm 0.01$ & $\begin{array}{l}0.24 \pm \\
0.35\end{array}$ & $\begin{array}{l}13.7 \pm \\
0.41\end{array}$ & $\begin{array}{l}0.96 \pm \\
0.01\end{array}$ & $\begin{array}{l}0.54 \pm \\
0.001\end{array}$ \\
\hline RIV1 & $\begin{array}{l}6.00 \\
\pm \\
0.00\end{array}$ & $26.7 \pm 0.10$ & $\begin{array}{l}61.9 \pm \\
0.10\end{array}$ & $\begin{array}{l}364 \pm \\
0.58\end{array}$ & $0.41 \pm 0.02$ & $\begin{array}{l}0.32 \pm \\
0.02\end{array}$ & $\begin{array}{l}62.6 \pm \\
0.77\end{array}$ & $\begin{array}{l}4.58 \pm \\
0.002\end{array}$ & $\begin{array}{l}0.14 \pm \\
0.003\end{array}$ \\
\hline RIV2 & $\begin{array}{l}7.22 \\
\pm \\
0.07\end{array}$ & $29.7 \pm 0.10$ & $59.9 \pm 0.10$ & $\begin{array}{l}965 \pm \\
0\end{array}$ & $0.56 \pm 0.02$ & $\begin{array}{l}0.51 \pm \\
0.02\end{array}$ & $\begin{array}{l}238.7 \pm \\
1.44\end{array}$ & $\begin{array}{l}0.64 \pm \\
0.001\end{array}$ & $\begin{array}{l}0.26 \pm \\
0.001\end{array}$ \\
\hline RIV3 & $\begin{array}{l}6.63 \\
\pm \\
0.10\end{array}$ & $25.0 \pm 0.20$ & $\begin{array}{l}255.5 \pm \\
1.30\end{array}$ & $\begin{array}{l}580 \pm \\
2.6\end{array}$ & $2.09 \pm 0.09$ & $\begin{array}{l}2.06 \pm \\
0.61\end{array}$ & $\begin{array}{l}49.9 \pm \\
0.53\end{array}$ & $\begin{array}{l}0.33 \pm \\
0.01\end{array}$ & $\begin{array}{l}0.14 \pm \\
0.001\end{array}$ \\
\hline $\begin{array}{l}\text { WQG for the } \\
\text { Leeuspruit } \\
\text { Catchment }\end{array}$ & $\begin{array}{l}6- \\
8.5\end{array}$ & - & $<45$ & - & 0.5 & 0.2 & - & 0.3 & $<8$ \\
\hline
\end{tabular}

Figure 2: Growth performance of Vetiver grass in the experiment (a) tolerance index (TI) of Vetiver grass with different treatments, (b) Vetiver grass in the AT2.5VT treatment appearing healthy at the end of the experiment. Values are means \pm standard deviations $n=3(p \leq 0.05)$. Error bars represent percent (\%) errors. Key: VT: Vetiver grass only; AT1VT: Vetiver + attapulgite (1\% W/V); AT2.5VT: Vetiver + attapulgite $(2.5 \% \mathrm{w} / \mathrm{V}) ; B T 1 \mathrm{VT}$ : Vetiver + bentonite $(1 \% \mathrm{w} / \mathrm{V}) ; B T 2.5 \mathrm{VT}$ : Vetiver + bentonite $(2.5 \% \mathrm{w} / \mathrm{v})$.

Figure 3: Growth performance of Vetiver grass in the experiment (a) tolerance index ( $\mathrm{TI}$ ) of Indian mustard in the different treatments, (b) Indian mustard in the AT2.5BJ treatment, appearing pale and yellowish by the end of the experiment. *Values are Means \pm standard deviations $n=3(p \leq 0.05)$. Error bars represent percent (\%) errors. Key: BJ: Indian mustard only; AT1BJ: Indian mustard + attapulgite (1\%

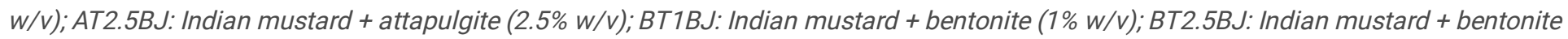
$(2.5 \% w / v)$.

The comparison of the TI obtained for Indian mustard and Vetiver within the different treatment groups showed that there were no statistically significant differences $(p>0.05)$. Vetiver grass with attapulgite applied at $2.5 \%(\mathrm{w} / \mathrm{v})$ showed the highest $\mathrm{Tl}$, while Indian mustard with attapulgite applied at the same rate showed the lowest TI. This variation may be due to the plants' different morphological and cellular traits (Beniah Obinna and Ebere 2019). Attapulgite and bentonite did not necessarily favour an increase in heavy metal tolerance and growth of Indian mustard, but they successfully improved the growth and tolerance of Vetiver grass in Al and Mn contaminated water.

iii. Heavy-metal accumulation

At the end of the experiment, the concentration of $\mathrm{Al}$ and $\mathrm{Mn}$ was significantly reduced in the vegetated treatments compared to the unvegetated treatments (Table 3). The treatments comprising both clay minerals and plants showed higher heavy metal removal. In some of the treatments, the resulting concentration of $\mathrm{Al}$ and $\mathrm{Mn}$ was higher than the initial concentrations (Table 3). This was because more contaminated water was added to the initial $800 \mathrm{~mL}$ mark as the water evaporated or transpired, leading to an increasing concentration of heavy metals. The desired outcome was to determine the effects of attapulgite and bentonite on the growth rate and heavy metal accumulation of Vetiver grass. The experiment revealed the quantity of Al and $\mathrm{Mn}$ that the plants could take up in 21 days under different treatments. For the clay-only treatments, there may have been a regeneration of contaminants that were previously adsorbed. This explains the increased Al and Mn in some treatments that were expected to have been adsorbed by the clay minerals (Li et al., 2019; Said et al., 2020).

A statistically significant difference $(p=0.014)$ was recorded in the absorbed concentration of Al and $\mathrm{Mn}$ between the treatments, as well as in their roots and shoots (Figures 4 and 5). There was generally higher root uptake of both heavy metals in all the treatments. The significant variance in root and shoot uptake corresponds to the findings of previous studies and confirms that Vetiver accumulates most heavy metals in its roots, because of its high tolerance (Suelee et al., 2017; Hassan et al., 2020; Gravand and Rahnavard, 2021). This was confirmed in all the treatments with Vetiver, even those with attapulgite and bentonite. 
Table 3

Residual Al and Mn contents in Vetiver grass under various treatments

\begin{tabular}{|c|c|c|c|c|c|c|c|c|c|c|}
\hline $\begin{array}{l}\text { Heavy } \\
\text { metals }\end{array}$ & $\begin{array}{l}\text { OT } \\
(\mathrm{mg} / \mathrm{l})\end{array}$ & $\begin{array}{l}\text { BT1 } \\
(\mathrm{mg} / \mathrm{l})\end{array}$ & $\begin{array}{l}\text { BT1VT } \\
(\mathrm{mg} / \mathrm{l})\end{array}$ & $\begin{array}{l}\text { AT2.5VT } \\
(\mathrm{mg} / \mathrm{l})\end{array}$ & $\begin{array}{l}\text { BT2.5VT } \\
(\mathrm{mg} / \mathrm{l})\end{array}$ & $\begin{array}{l}\text { BT2.5 } \\
(\mathrm{mg} / \mathrm{l})\end{array}$ & $\begin{array}{l}\mathrm{VT} \\
(\mathrm{mg} / \mathrm{l})\end{array}$ & $\begin{array}{l}\text { AT1VT } \\
(\mathrm{mg} / \mathrm{l})\end{array}$ & $\begin{array}{l}\text { AT2.5 } \\
(\mathrm{mg} / \mathrm{l})\end{array}$ & $\begin{array}{l}\text { AT1 } \\
(\mathrm{mg} / \mathrm{l})\end{array}$ \\
\hline Mn & $\begin{array}{l}24,5 \pm \\
8,21\end{array}$ & $13 \pm 7,85$ & $\begin{array}{l}0,1 \pm \\
0,11\end{array}$ & $\begin{array}{l}1,6 \pm \\
1,02\end{array}$ & $\begin{array}{l}0,5 \pm \\
0,26\end{array}$ & $\begin{array}{l}2,9 \pm \\
0,67\end{array}$ & $\begin{array}{l}16,8 \pm \\
3,82\end{array}$ & $3,8 \pm 3,3$ & $\begin{array}{l}0,7 \pm \\
0,08\end{array}$ & $\begin{array}{l}15,1 \pm \\
1,44\end{array}$ \\
\hline Al & $\begin{array}{l}39,3 \pm \\
15,93\end{array}$ & $\begin{array}{l}30,9 \pm \\
23,53\end{array}$ & $\begin{array}{l}0,7 \pm \\
0,61\end{array}$ & $\begin{array}{l}3,4 \pm \\
6,01\end{array}$ & $\begin{array}{l}2,9 \pm \\
2,44\end{array}$ & $\begin{array}{l}17,5 \pm \\
2,46\end{array}$ & $\begin{array}{l}15,9 \pm \\
5,42\end{array}$ & $\begin{array}{l}14,5 \pm \\
19,22\end{array}$ & $\begin{array}{l}1,2 \pm \\
0,08\end{array}$ & $\begin{array}{l}2,1 \pm \\
0,42\end{array}$ \\
\hline
\end{tabular}

Figure 4: Manganese (Mn) accumulation in (a) roots and (b) shoots of Vetiver grass. *Values are Means \pm standard deviations $n=3$ ( $p \leq$ 0.05). Error bars represent percent (\%) errors. Key: VT: Vetiver grass only; AT1VT: Vetiver + attapulgite (1\% w/v); AT2.5VT: Vetiver + attapulgite $(2.5 \% \mathrm{~W} / \mathrm{V})$; BT1VT: Vetiver + bentonite $(1 \% \mathrm{~W} / \mathrm{V})$; BT2.5VT: Vetiver + bentonite $(2.5 \% \mathrm{w} / \mathrm{V})$.

Figure 5: Aluminium (Al) accumulation in (a) roots and (b) shoots of Vetiver grass. *Values are Means \pm standard deviations $n=3$ ( $p \leq 0.05$ ). Error bars represent percent (\%) errors. Key: VT: Vetiver grass only; AT1VT: Vetiver + attapulgite (1\% w/V); AT2.5VT: Vetiver + attapulgite $(2.5 \% \mathrm{w} / \mathrm{V}) ;$ BT1VT: Vetiver + bentonite $(1 \% \mathrm{w} / \mathrm{V}) ;$ BT2.5VT: Vetiver + bentonite $(2.5 \% \mathrm{w} / \mathrm{V})$.

The absorption of Al (Figure 5) was generally higher than that of Mn (Figure 4) in both roots and shoots, probably because the initial concentration of $\mathrm{Al}$ in the water was five times greater than that of $\mathrm{Mn}$, and in most cases, heavy metal accumulation in plants increases with increasing concentration in the substrates (He et al., 2021; Hussain et al., 2021; Leng et al., 2021). In addition, Al could have reduced the availability of Mn because it exhibits an antagonistic behaviour towards Mn uptake (Yang et al., 2009). Al has more affinity to FeOH than $\mathrm{Mn}$, therefore the iron plaques might also play an important role in this process. In previous studies, Vetiver showed more preference for Mn than other heavy metals, without a significant change in biomass yield even at high concentrations (Hassan et al., 2020; Thakur et al., 2021). For Mn, AT1VT showed the highest root uptake (28.6 ppm) while the VT (Vetiver only treatment) showed the least root uptake (7.9 ppm). The highest shoot uptake of 6.1 ppm was, however, observed in the VT treatment. According to Thakur et al. (2021), when heavy metals are taken up into plant cells, they can be excluded, immobilized, chelated, or compartmentalized. Therefore, cell growth determines biomass yield, which in turn promotes metals absorption (Ali et al., 2013). For Al, treatment BT2.5VT showed the highest root and shoot uptake of 330.7 and $41.1 \mathrm{ppm}$, respectively, while the lowest root and shoot uptake was observed in treatment VT. There was a strong positive correlation between root and shoot Al absorption by Vetiver grass $(r=0.90, p<0.05)$, while a weak positive coefficient was observed between Mn root and shoot uptake $(r=0.01, p<0.05)$.

Generally, there was no significant uptake of Al and Mn by Indian mustard in all treatments, as none of the heavy metals were detected by ICP-OES. This was attributed to the increasing concentrations of contaminated water in the experimental pots. The final concentration in the untreated water was 25.4 and 39.3 ppm for $\mathrm{Mn}$ and $\mathrm{Al}$, respectively (Table 3). These final concentrations resulted from the continual addition of contaminated water each time the initial volume was reduced by evaporation, transpiration and plant uptake. Phytoremediation studies indicate that this method is suitable for minimally contaminated sites (Beniah Obinna and Ebere, 2019). Although none of the plants died during the experiment, the resulting toxicity from increasing heavy metal concentration was likely to be responsible for the inability of Indian mustard to absorb Al and Mn significantly.

Previous studies indicated that Indian mustard can absorb high concentrations of metals (50-30,000 ppm) in water (Meyers et al., 2008; Singh and Fulekar, 2012; Napoli et al., 2019). However, studies have also indicated that Indian mustard performs better as a phytoremediation plant when only one metal type is present compared to when two or more metals or when heavy metal contaminants are present. For example, Yang et al. (2021) reported that Indian mustard performed better as a hyperaccumulator when only As or Pb was present compared to when both heavy metals were present. The authors noted up to $90 \%$ decrease in As absorption when Pb was present as a co-contaminant in solution, whereas, in As only solution, Indian mustard absorbed up to 1,786 ppm. Kim et al. (2010) observed a reduced uptake of $\mathrm{Cd}, \mathrm{Cu}, \mathrm{Pb}$, and $\mathrm{Zn}$ due to the presence of multiple metals and competitive uptake of these metals. Chigbo et al. (2013) reported up to $85 \%$ decrease in $\mathrm{Cu}$ accumulation by $\mathrm{B}$. juncea and a decrease of biomass in the presence of pyrene. The decrease in Cu accumulation was attributed to reactions of complexes with root exudates and pyrene (Jeelani et al., 2020), resulting in the formation of insoluble Cu complexes, thus limiting uptake.

The insignificant metal uptake by Indian mustard could also result from Mn-induced toxicity, which have been reported previously (Parashar

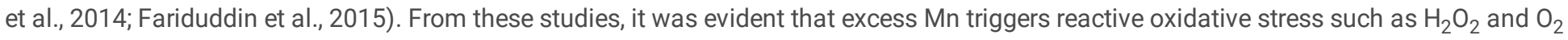
radicals in Indian mustard, threatening proper plant growth after damage to membrane lipids, stomatal functions, proteins, and enzymes

Page 7/14 
(Parashar et al., 2014). Crop productivity is dependent on several factors such as aeration, irrigation and abiotic stresses (Phusantisampan et al., 2016). According to Gayatri et al. (2019), higher contents of trace elements including Zn, Ni, Mn, Cu and Fe can inhibit plant growth and lead to toxicity in plants. This is likely to be the case with Indian mustard in this study, but the growth of Vetiver grass was not inhibited by $\mathrm{Al}$ and Mn toxicity. Increasing concentrations of Al and Mn may have lowered the ability of Indian mustard cells to function properly, thereby limiting its metabolic, morphological and absorptive properties (Srivastava et al., 2015; Phusantisampan et al., 2016). Mn and Al induce oxidative stress in Indian mustard, restrict plant growth, cell elongation and photosynthesis, leading to stunting (Fariduddin et al., 2015; Ahmad et al., 2018). In this study, attapulgite and bentonite could not increase heavy metal absorption by Indian mustard, neither could these clay minerals alleviate heavy metal stress in the plant.

iv. Translocation factor (TF)

Translocation factor values $<1$ indicate a plant is suitable for phytostabilisation or root storage of heavy metals, and TF values $>1$ indicate suitability for phytoextraction (Beniah Obinna and Ebere, 2019). The TF for all treatments was less than 1 (Table 4 ), although Mn showed a higher translocation to the shoots of Vetiver compared to Al in all the treatments (Table 4). The highest TF of 0.78 was observed in the VT treatment for $\mathrm{Mn}$, indicating that attapulgite and bentonite might have prevented translocation of Mn by promoting stronger adsorption of $\mathrm{Mn}$ within the root zone. According to Ramos-Arcos et al. (2019), the removal of Mn was the fastest among heavy metals including Al, B, Ba, $\mathrm{Be}, \mathrm{Co}, \mathrm{Cr}, \mathrm{Cu}, \mathrm{Fe}, \mathrm{Mg}, \mathrm{Ni}, \mathrm{Pb}, \mathrm{S}, \mathrm{Se}, \mathrm{Tl}, \mathrm{V}$ and $\mathrm{Zn}$, but TF was $<1$. This is similar to the present study as TF values below 1 (ranging between 0.22 to 0.77 ) were observed for Mn in Vetiver grass. Another study showed that within 30 days, $0.15 \mathrm{ppm}$ of Mn can be removed from landfill leachate by Vetiver grass (Thakur et al., 2021), with TF $>1$. The high TF observed in the study may have been due to the low initial concentration of $\mathrm{Mn}$, which encouraged faster translocation (Thakur et al., 2021). For Al, the highest TF of $\sim 0.14$ was observed in the AT2.5VT treatment (Table 4), but reasonable amounts of Al were stored within the roots of Vetiver. Generally, results indicated that the roots of Vetiver grass could both tolerate and accumulate high concentrations of $\mathrm{Mn}$ and $\mathrm{Al}$.

Table 4

Translocation factor (TF) observed for Vetiver grass in each treatment

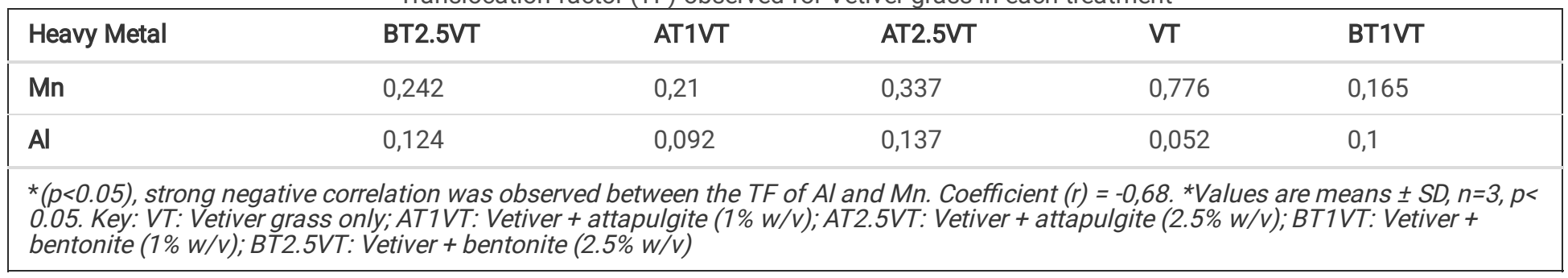

The low TF observed in this study was similar to the findings of Suelee et al. (2017) and Thakur et al. (2021). The cell membrane is negatively charged; therefore, $\mathrm{Mn}$ and $\mathrm{Al}$ ions enter plant cells easily. However, $\mathrm{Mn}$ is more easily translocated to the shoots because it is an essential element for plant growth (Ramos-Arcos et al., 2019; Shahid et al., 2020; Thakur et al., 2021). Although the TF indicates a plant's ability to translocate heavy metals to its shoots, it should not be solely considered when determining the suitability of plants as hyperaccumulators, because although $\mathrm{TF}<1$, the shoots may still have absorbed high levels of heavy metals. For instance, in a study on the absorption of Cd by Himalayan balsam, TF was < 1, but the plant's shoots contained about $70 \%$ of the total Cd root uptake (Coakley et al., 2019). The TF was < 1 for Al and Mn in this study, a situation that can be considered an advantage, because it prevents metals from reaching the plant shoots and damaging the photosynthetic machinery as well as limiting post-remediation use of Vetiver grass (Beniah Obinna and Ebere, 2019). This also prevents the heavy metals from getting into the food chain (if animals eat shoots and leaves).

\section{Conclusion}

The study investigated the TI and heavy metal accumulation ability of Vetiver grass and Indian mustard to simultaneously remove Al and Mn from contaminated water in a hydroponic system. Results from the experiment demonstrated that while Vetiver grass could bioaccumulate significant amounts of both heavy metals in its roots within 21 days, Indian mustard could not absorb significant amounts of $\mathrm{Al}$ and $\mathrm{Mn}$ that could be detected by ICP-OES analysis of the digested plants. In Vetiver grass, the uptake of Al and Mn in the roots was more than two-fold that of the shoot uptake in most of the treatments. In addition, there was low Al and Mn translocation, as the TI in all the treatments were $<1$.

Attapulgite and bentonite successfully increased the tolerance index and heavy metal phytoremediation potential of Vetiver grass. These results suggest that Vetiver grass can be a suitable candidate for removal of Al and $\mathrm{Mn}$ in water under controlled greenhouse conditions and its performance can be improved by the addition of clay minerals such as bentonite added at 2.5\% (w/v), which performed best for Al 
remediation and significantly good for $\mathrm{Mn}$. Therefore, it is recommended that the efficacy of this combination of Vetiver grass and clay minerals be tested under field (natural) conditions to ascertain full scale application for heavy-metal contaminated waters. Field studies would be recommendable to test the application of bentonite to improve the phytoremediation capacity of Vetiver grass in $\mathrm{Al}$ and $\mathrm{Mn}$ contaminated river water. If similar results are obtained in field trials, then bentonite could be confirmed as a beneficial material for improving the phytoremediation capacity of Vetiver grass. This is the first study to prove that the use of bentonite improves the performance of the Vetiver grass during phytoremediation of heavy metals such as $\mathrm{Al}$ and $\mathrm{Mn}$.

\section{Declarations}

\section{Availability of data and Materials}

The authors confirm that the data supporting the findings of this study are available within this published article.

\section{Acknowledgements}

The authors would like to thank Hydromulch (Pty) Ltd, Johannesburg, South Africa, for sponsoring the vetiver grass used in this research.

The authors are grateful to AttaClay (Pty) Ltd, Germiston, South Africa, for sponsoring the clay minerals (bentonite and attapulgite) that were used in this study.

\section{Statements and Declarations}

\section{Funding}

Funding was provided by the Faculty of Natural and Agricultural Sciences Central Research Fund, University of the Free State.

\section{Competing Interests}

The authors declare that they have no known competing financial interests or personal relationships that could have appeared to influence the work reported in this paper.

\section{Authors Contributions}

Beatrice Omonike Otunola, Makhosazana Aghoghovwia, Melusi Thwala and Olusola Oluwayemisi Ololade contributed to the study conception and design. Beatrice Omonike Otunola, Alba Gómez-Arias, Rian Jordaan and Julio Castillo Hernandez contributed to chemical analysis and interpretation. Literature search and first draft of the manuscript was done by Beatrice Omonike Otunola. All authors contributed to the critical revision of manuscript and approved the final manuscript.

\section{Consent to Participate}

All the authors consented to participate in the drafting and submission of this manuscript.

\section{Consent for Publication}

All the authors consented to publish this manuscript.

\section{Ethics approval}

Not applicable.

\section{References}

1. Ali H, Khan E, Sajad MA (2013) Phytoremediation of heavy metals-concepts and applications. Chemosphere, 91(7), pp.869-881. doi: 10.1016/j.chemosphere.2013.01.075

2. Ali AE, Sloane DR, Strezov V (2018) Assessment of impacts of coal mining in the region of Sydney, Australia on the aquatic environment using macroinvertebrates and chlorophyll as indicators. Int J Environ Res Public Health 15(7):1556

3. Ahmad J, Baig MA, Ali AA, Al-Huqail AA, Ibrahim MM, Qureshi MI (2018) Differential antioxidative and biochemical responses to aluminium stress in Brassica juncea cultivars. Hortic Environ Biotechnol 59(5):615-627 
4. Beniah Obinna I, Ebere *Enyoh Christian (2019) 'A review: Water pollution by heavy metal and organic pollutants: Brief review of sources, effects and progress on remediation with aquatic plants'. Analytical Methods in Environmental Chemistry Journal, (September), 5-38. doi: 10.24200/amecj.v2.i03.66

5. Betancourt Ó, Tapia M, Méndez I (2015) Decline of General Intelligence in Children Exposed to Manganese from Mining Contamination in Puyango River Basin, Southern Ecuador. EcoHealth 12, 453-460 https://doi.org/10.1007/s10393-015-1027-2

6. Coakley S, Cahill G, Enright AM, O'Rourke B, Petti C (2019) Cadmium hyperaccumulation and translocation in Impatiens glandulifera: from foe to friend? Sustainability 11(18):5018

7. Chigbo C, Batty L, Bartlett R (2013) Interactions of copper and pyrene on phytoremediation potential of Brassica juncea in copperpyrene co-contaminated soil. Chemosphere 90(10):2542-2548. https://doi.org/10.1016/j.chemosphere.2012.11.007

8. Danh LT, Truong P, Mammucari R, Tran T, Foster N (2009) Vetiver grass, Vetiveria zizanioides: a choice plant for phytoremediation of heavy metals and organic wastes. Int J Phytoremediation 11(8):664-691. doi: 10.1080/15226510902787302

9. Edgar VN, Fabián FL, Mario PCJ, lleana VR (2021) Coupling Plant Biomass Derived from Phytoremediation of Potential Toxic-MetalPolluted Soils to Bioenergy Production and High-Value by-Products-A Review. Applied Sciences 11(7):2982. doi: 10.3390/app11072982

10. Fariduddin Q, Ahmed M, Mir BA, Yusuf M, Khan TA (2015) 24-Epibrassinolide mitigates the adverse effects of manganese induced toxicity through improved antioxidant system and photosynthetic attributes in Brassica juncea. Environ Sci Pollut Res 22(15):1134911359. doi: 10.1007/s11356-015-4339-4

11. Gayatri N, Sailesh AR, Srinivas N (2019) Phytoremediation Potential of Brassica juncea for removal of selected heavy metals in urban soil amended with cow dung. J Mater Environ Sci 10(5):463-469

12. Gravand F, Rahnavard A (2021) 'Advances in Clinical Toxicology Evaluation of Changes in the Uptake of Heavy Metals in Leachate using Vetiver Phytoremediation'., pp. 11-14.. doi: 10.23880/act-16000207

13. Hassan MM, Haleem N, Baig MA, Jamal Y (2020) Phytoaccumulation of heavy metals from municipal solid waste leachate using different grasses under hydroponic condition. Sci Rep 10(1):1-8. doi: 10.1038/s41598-020-72800-2

14. He W, Long A, Zhang C, Cao M, Luo J (2021) Mass balance of metals during the phytoremediation process using Noccaea caerulescens: a pot study. Environ Sci Pollut Res 28(7):8476-8485. doi: 10.1007/s11356-020-11216-x

15. Hussain F, Hadi F, Rongliang Q (2021) 'Effects of zinc oxide nanoparticles on antioxidants, chlorophyll contents, and proline in Persicaria hydropiper L. and its potential for Pb phytoremediation'. Environ Sci Pollut Res 28(26):34697-34713. doi: 10.1007/s11356021-13132-0

16. Iloms E, Ololade OO, Ogola HJ, Selvarajan R (2020) Investigating industrial effluent impact on municipal wastewater treatment plant in Vaal, South Africa. Int J Environ Res Public Health 17(3):1096

17. In-stream Water Quality Guidelines for the Leeuspruit

Catchmenthttps://www.reservoir.co.za/forums/vaalbarrage/leeutaai_forum/leeutaai_documents/LTF_WQGuidelines_Leeu.pdfAccessed 26 September 2021

18. Itam MO, Nnamani CV, Oku EE (2019) 'African Vetiver grass cleans abattoir effluent'. Agriculture and Natural Resources 53(3):260-266. doi: 10.34044/j.anres.2019.53.3.07

19. Jeelani N, Yang W, Zhu HL, An S (2020) Phytoremediation for co-contaminated soils of cadmium and pyrene using Phragmites australis (common reed). Int J Phytoremediation 22(13):1385-1395. https://doi.org/10.1080/15226514.2020.1780411

20. Katoh M, Hashimoto K, Sato T (2016) Lead and antimony removal from contaminated soil by phytoremediation combined with an immobilisation material. Clean-soil, air, water 44(12):1717-1724

21. Kiiskila JD, Sarkar D, Panja S, Sahi SV, Datta R (2019) Remediation of acid mine drainage-impacted water by vetiver grass (Chrysopogon zizanioides): A multiscale long-term study. Ecol Eng 129:97-108. https://doi.org/10.1016/j.ecoleng.2019.01.018

22. Kim KR, Owens G, Kwon SL (2010) Influence of Indian mustard (Brassica juncea) on rhizosphere soil solution chemistry in long-term contaminated soils: a rhizobox study. J Environ Sci 22(1):98-105. https://doi.org/10.1016/S1001-0742(09)60080-2

23. Kome GK, Enang RK, Tabi FO, Yerima BPK (2019) Influence of clay minerals on some soil fertility attributes: a review. Open Journal of Soil Science 9(9):155-188

24. Koupai JA, Jamalian MA, Dorafshan MM (2020) 'I mproving Isfahan Landfill Leachate Quality by Phytoremediation Using Vetiver and Phragmites Plants in Green Space Irrigation', Journal of Water and Wastewater, Vol. 31, No.3, pp: 101-111, 31(3), pp. 101-111. doi: 10.22093/wwj.2019.186145.2867

25. Leng Y, Lu M, Li F, Yang B, Hu ZT (2021) Citric acid-assisted phytoextraction of trace elements in composted municipal sludge by garden plants. Environ Pollut 288:117699. doi: 10.1016/j.envpol.2021.117699

Page $10 / 14$ 
26. Li Y, Xu Z, Ma H, Hursthouse S, A (2019) Removal of Manganese (II) from acid mine wastewater: A review of the challenges and opportunities with special emphasis on mn-oxidizing bacteria and microalgae. Water 11(12):2493

27. Meyers DE, Auchterlonie GJ, Webb RI, Wood B (2008) Uptake and localisation of lead in the root system of Brassica juncea. Environ Pollut 153(2):323-332. https://doi.org/10.1016/j.envpol.2007.08.029

28. Mezgebe K, Gebrekidan A, Hadera A, Weldegebriel Y (2015) Assessment of physico-chemical parameters of tsaedaagam river in mekelle city, tigray, Ethiopia. Bull Chem Soc Ethiop 29(3):377-385

29. Mioska MJ (2012) 'A column experiment for groundwater remediation post-mine closure at the Wolverine Mine, Yukon', ProQuest Dissertations and Theses, (March 2012), p. 117

30. Napoli M, Cecchi S, Grassi C, Baldi A, Zanchi CA, Orlandini S (2019) Phytoextraction of copper from a contaminated soil using arable and vegetable crops. Chemosphere 219:122-129. https://doi.org/10.1016/j.chemosphere.2018.12.017

31. Otunola BO, Ololade 00 (2020) 'A review on the application of clay minerals as heavy metal adsorbents for remediation purposes'. Environmental Technology and Innovation 18:100692. doi: 10.1016/j.eti.2020.100692

32. Parashar A, Yusuf M, Fariduddin Q, Ahmad A (2014) Salicylic acid enhances antioxidant system in Brassica juncea grown under different levels of manganese. Int J Biol Macromol 70:551-558

33. Paz-Ferreiro J, Lu H, Fu S, Méndez A, Gascó G (2014) Use of phytoremediation and biochar to remediate heavy metal polluted soils: a review. Solid earth, 5(1), p.65

34. Phusantisampan T, Meeinkuirt W, Saengwilai P, Pichtel J, Chaiyarat R (2016) Phytostabilization potential of two ecotypes of Vetiveria zizanioides in cadmium-contaminated soils: greenhouse and field experiments. Environ Sci Pollut Res 23(19):20027-20038. doi: 10.1007/s11356-016-7229-5

35. Qadir S, Qureshi MI, Javed S, Abdin MZ (2004) Genotypic variation in phytoremediation potential of Brassica juncea cultivars exposed to Cd stress. Plant Sci 167(5):1171-1181. doi: 10.1016/j.plantsci.2004.06.018

36. Raj D, Kumar A, Maiti SK (2020) 'Brassica juncea (L.) Czern. (Indian mustard): a putative plant species to facilitate the phytoremediation of mercury contaminated soils'. Int J Phytoremediation 22(7):733-744. doi: 10.1080/15226514.2019.1708861

37. Ramos-Arcos SA, López-Martínez S, Rivera L, De La Cruz Leyva SGONZÁLEZMONDRAGÓNE, Velázquez-Martínez JR (2019) Phytoremediation of landfill leachate using vetiver (Chrysopogon zizanioides) and cattail (Typha latifolia). Appl Ecol Environ Res 17(2):2619-2630. doi: 10.15666/aeer/1702_26192630

38. Hamid R, Parray JA, Kamili AN, Mahmooduzzafar M (2012) Chromium stress in Brassica juncea L. cv.'Pusa Jai Kissan'under hydroponic culture. Afr J Biotechnol 11(90):15658-15663. doi: 10.5897/ajb11.3564

39. Said NSM, Abdullah SRS, Ismail NI, Hasan HA, Othman AR (2020) Phytoremediation of real coffee industry effluent through a continuous two-stage constructed wetland system. Environmental Technology \& Innovation 17:100502. doi: 10.1016/j.eti.2019.100502

40. Salimizadeh M, Shirvani M, Shariatmadari H, Mortazavi MS (2020) Bentonite addition to a PCB-contaminated sandy soil improved the growth and phytoremediation efficiency of Zea mays L. and Alternanthera sessilis L. Int J Phytoremediation 22(2):176-183

41. Sastre J, Sahuquillo A, Vidal M, Rauret G (2002) Determination of Cd, Cu, Pb and Zn in environmental samples microwave-assisted total digestion versus aqua regia and nitric acid extraction. Anal Chim Acta 462:59-72

42. Shahid MJ, Ali S, Shabir G, Siddique M, Rizwan M, Seleiman MF, Afzal M (2020) Comparing the performance of four macrophytes in bacterial assisted floating treatment wetlands for the removal of trace metals ( $\mathrm{Fe}, \mathrm{Mn}, \mathrm{Ni}, \mathrm{Pb}$, and $\mathrm{Cr}$ ) from polluted river water. Chemosphere 243:125353. doi: 10.1016/j.chemosphere.2019.125353

43. Sharma P (2021) 'Efficiency of bacteria and bacterial assisted phytoremediation of heavy metals: An update', Bioresource Technology, 328(December 2020), p. 124835. doi: 10.1016/j.biortech.2021.124835

44. Singh A, Fulekar MH (2012) Phytoremediation of heavy metals by Brassica juncea in aquatic and terrestrial environment. The plant family Brassicaceae. Springer, Dordrecht, pp 153-169

45. Sricoth T, Meeinkuirt W, Pichtel J, Taeprayoon P, Saengwilai P (2018) Synergistic phytoremediation of wastewater by two aquatic plants (Typha angustifolia and Eichhornia crassipes) and potential as biomass fuel. Environ Sci Pollut Res 25(6):5344-5358. doi: 10.1007/s11356-017-0813-5

46. Srivastava S, Srivastava AK, Sablok G, Deshpande TU, Suprasanna P (2015) Transcriptomics profiling of Indian mustard (Brassica juncea) under arsenate stress identifies key candidate genes and regulatory pathways. Front Plant Sci 6:646. doi: 10.3389/fpls.2015.00646

47. Suelee AL, Hasan SNMS, Kusin FM, Yusuff FM, Ibrahim ZZ (2017) Phytoremediation potential of vetiver grass (Vetiveria zizanioides) for treatment of metal-contaminated water. Water Air Soil Pollut 228(4):158. doi: 10.1007/s11270-017-3349-x 
48. Thakur LS, Varma AK, Goyal H, Sircar D, Mondal P (2021) Simultaneous removal of arsenic, fluoride, and manganese from synthetic wastewater by Vetiveria zizanioides. Environ Sci Pollut Res 1-10. doi: 10.1007/s11356-021-13898-3

49. Truong P, Hartm BHMEC (2001) 'Vetiver System For Wastewater Treatment',Pacific Rim Vetiver Network Technical Bulletin, p.2

50. US EPA (2007) https://www.epa.gov/hw-sw846/sw-846-test-method-3051a-microwaveassisted-acid-digestion-sediments-sludges-soilsand-oils. Accessed 3 May, 2020

51. Vardhan KH, Kumar PS, Panda RC (2019) A review on heavy metal pollution, toxicity and remedial measures: Current trends and future perspectives. J Mol Liq 290:111197

52. Wang D, He Y, Liang J, Liu P, Zhuang P (2013) Distribution and source analysis of aluminum in rivers near Xi'an City. China Environmental monitoring and assessment 185(2):1041-1053

53. Water Quality Association (WQA, 2021) https://wqa.org/learn-about-water/water-q-a/manganese. Accessed 08 December 2021

54. Wessels L (2013) Decant of sigma colliery (Doctoral dissertation, University of the Free State)

55. World Health Organization (2017) Guidelines for drinking-water quality. Fourth edition Incorporating the first addendum. pp 1-631

56. Yang ZB, You JF, Xu MY, Yang ZM (2009) Interaction between aluminum toxicity and manganese toxicity in soybean (Glycine max). Plant Soil 319(1):277-289

57. Yang Y, Ge Y, Tu P, Zeng H, Zhou X, Zou D, Zeng Q (2019) Phytoextraction of Cd from a contaminated soil by tobacco and safe use of its metal-enriched biomass. J Hazard Mater 363:385-393

58. Yang W, Luo L, Bostick BC, Wiita E, Cheng Y, Shen Y (2021) Effect of combined arsenic and lead exposure on their uptake and translocation in Indian mustard. Environ Pollut 274:116549

59. Zotiadis V, Argyraki A (2013) Development of innovative environmental applications of attapulgite clay. Bulletin of the Geological Society of Greece 47. https://doi.org/10.12681/bgsg.11139

\section{Figures}

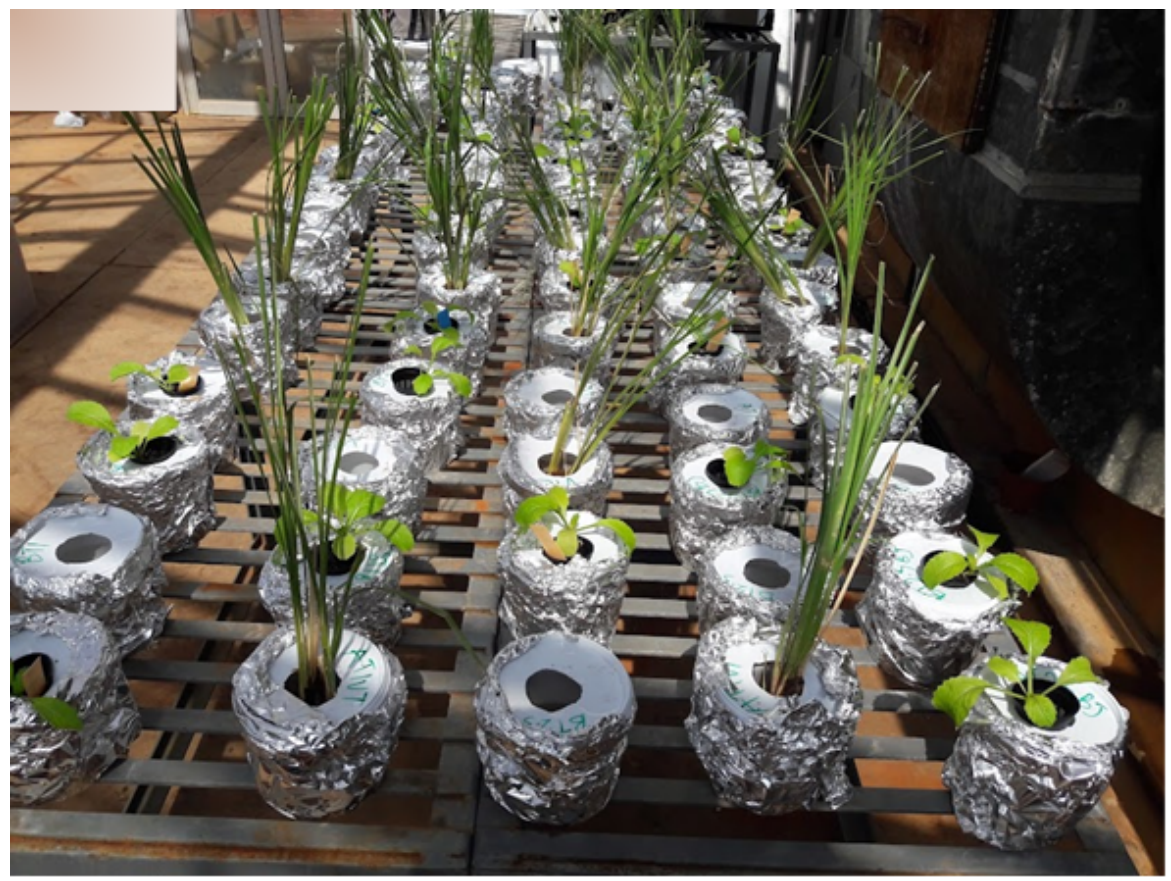

\section{Figure 1}

Experimental setup of the various treatments at a greenhouse facility, University of the Free State, South Africa. 


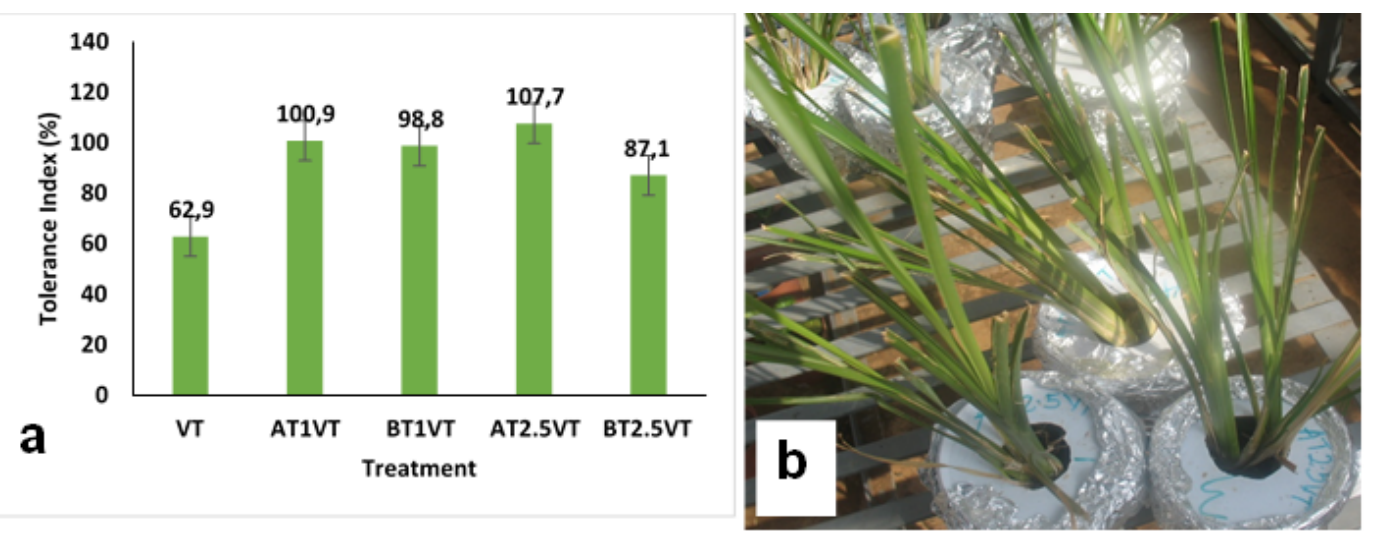

Figure 2

Growth performance of Vetiver grass in the experiment (a) tolerance index (TI) of Vetiver grass with different treatments, (b) Vetiver grass in the AT2.5VT treatment appearing healthy at the end of the experiment. Values are means \pm standard deviations $n=3$ ( $p \leq 0.05)$. Error bars represent percent (\%) errors. Key: VT: Vetiver grass only; AT1VT: Vetiver + attapulgite (1\% w/V); AT2.5VT: Vetiver + attapulgite (2.5\% w/v); BT1VT: Vetiver + bentonite $(1 \% \mathrm{w} / \mathrm{V}) ;$ BT2.5VT: Vetiver + bentonite $(2.5 \% \mathrm{w} / \mathrm{V})$.
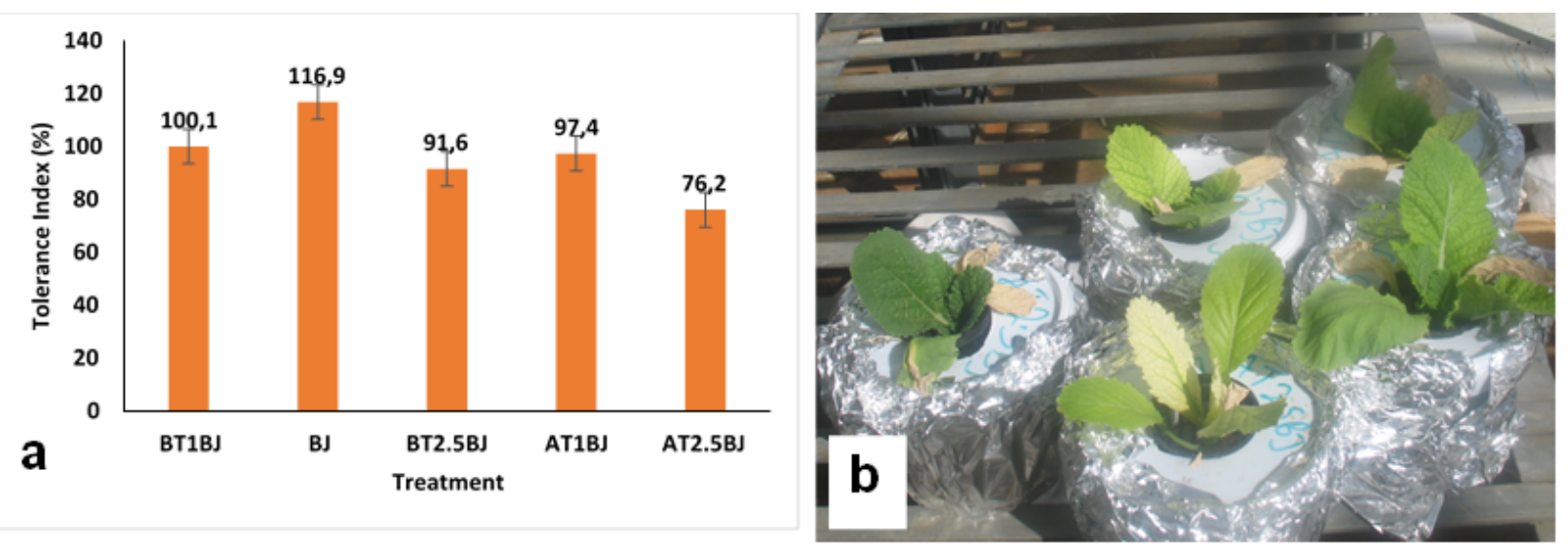

Figure 3

Growth performance of Vetiver grass in the experiment (a) tolerance index ( $\mathrm{TI}$ ) of Indian mustard in the different treatments, (b) Indian mustard in the AT2.5BJ treatment, appearing pale and yellowish by the end of the experiment. *Values are Means \pm standard deviations $n=3$ ( $p \leq 0.05)$. Error bars represent percent (\%) errors. Key: BJ: Indian mustard only; AT1BJ: Indian mustard + attapulgite (1\% w/v); AT2.5BJ: Indian mustard + attapulgite (2.5\% w/v); BT1BJ: Indian mustard + bentonite (1\% w/v); BT2.5BJ: Indian mustard + bentonite (2.5\% w/V).

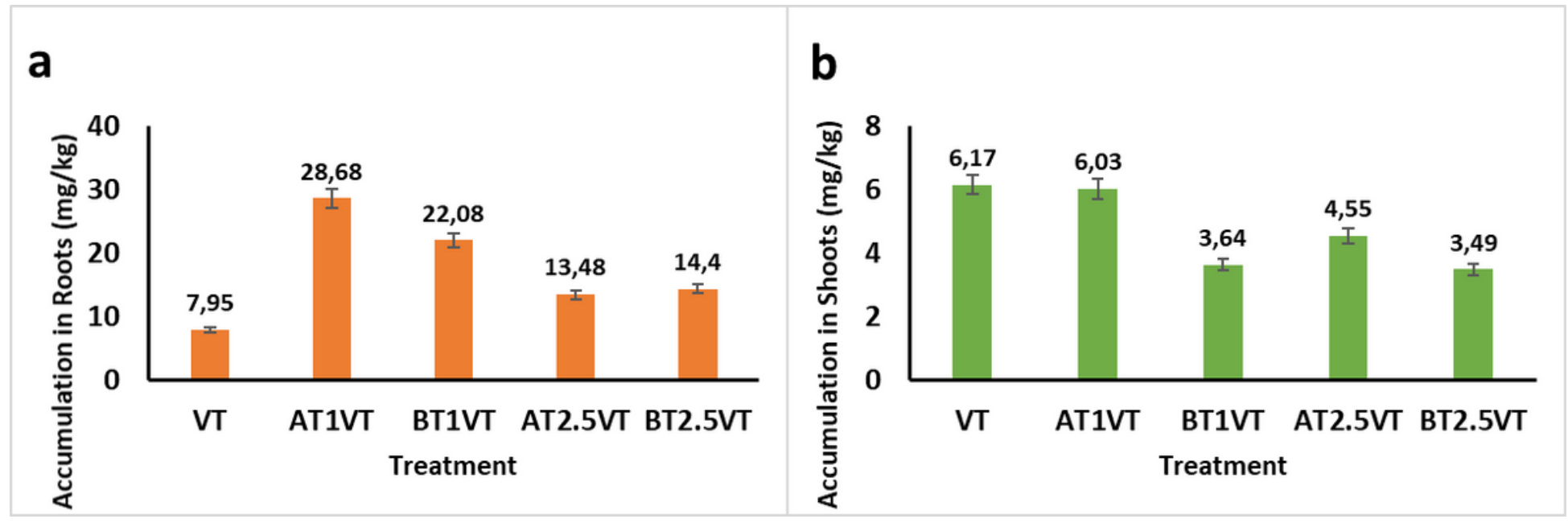

Figure 4 
Manganese (Mn) accumulation in (a) roots and (b) shoots of Vetiver grass. *Values are Means \pm standard deviations $n=3(p \leq 0.05)$. Error bars represent percent (\%) errors. Key: VT: Vetiver grass only; AT1VT: Vetiver + attapulgite (1\% w/v); AT2.5VT: Vetiver + attapulgite $(2.5 \%$ $\mathrm{W} / \mathrm{V}) ;$ BT1VT: Vetiver + bentonite $(1 \% \mathrm{~W} / \mathrm{V}) ; B T 2.5 \mathrm{VT}$ : Vetiver + bentonite $(2.5 \% \mathrm{~W} / \mathrm{V})$.

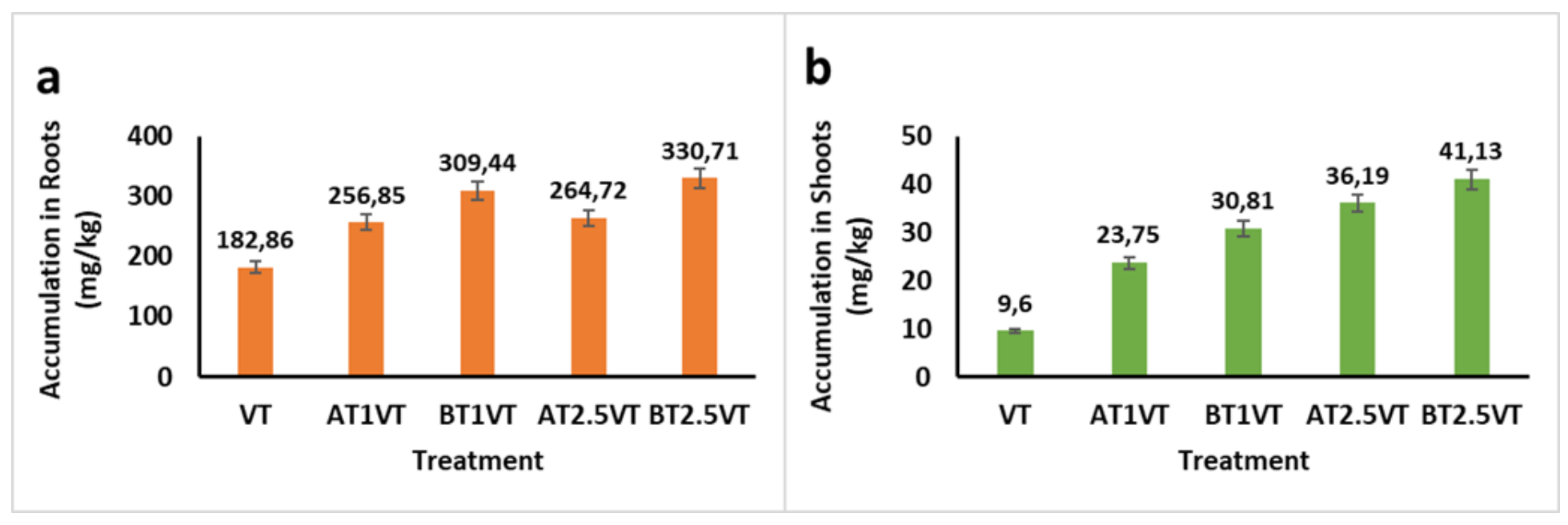

\section{Figure 5}

Aluminium (Al) accumulation in (a) roots and (b) shoots of Vetiver grass. *Values are Means \pm standard deviations $n=3(p \leq 0.05)$. Error bars represent percent (\%) errors. Key: VT: Vetiver grass only; AT1VT: Vetiver + attapulgite (1\% W/V); AT2.5VT: Vetiver + attapulgite $(2.5 \%$ $w / v) ; B T 1 V T$ : Vetiver + bentonite $(1 \% \mathrm{w} / \mathrm{v}) ;$ BT2.5VT: Vetiver + bentonite $(2.5 \% \mathrm{w} / \mathrm{V})$. 